NBER WORKING PAPER SERIES

\title{
DISCONTINUITIES IN PENSION BENEFIT \\ FORMULAS AND THE SPOT MODEL \\ OF THE LABOR MARKET:
}

IMPLICATIONS FOR FINANCIAL ECONOMISTS

James E. Pesando

Working Paper No. 1795

NATIONAL BUREAU OF ECONOMIC RESEARCH

1050 Massachusetts Avenue

Cambridge, MA 02138

January 1986

I am indebted to Jeremy Bulow, Richard Ippolito, Dan McGi11, Samuel

A Rea, Jr., and Jack VanDerhei for helpful comments, to Stan Zin for programming assistance and to the Social Sciences and Humanities Research Council of Canada for financial support. The research reported here is part of the NBER's research program in Financial Markets and Monetary Economics and project in Taxation and Capital Formation. Any opinions expressed are those of the author and not those of the National Bureau of Economic Research. 
NBER Working Paper \#1795

January 1986

Discontinuities in Pension Benefit Formulas and the Spot Model of the Labor Market: Irmplications for Financial Economists

\section{ABSTRACT}

When analyzing tax and related issues, financial economists typically invoke the simplest and the most tractable model of the labor market. This is the spot model, in which the worker's cash wage plus accruing pension benefit must equal the value of the worker's marginal product in each and every period. This paper first identifies the discontinuities in a worker's cash wage that must occur under the spot model if the pension plan has typical "cliff" vesting and early retirement provisions. The paper then calculates the pension benefits actually accrued, at and around the dates of eligibility for these benefits, by members of five pension plans in Canada. Both exercises serve to discredit the spot model. The paper reviews the underfunding puzzle, the measurement of pension liabilities, and the recapture of surplus assets in overfunded plans in light of these findings.

James E. Pesando Institute for Policy Analysis University of Toronto 140 St. George Street Suite 707 Toronto, Ontario CANADA M5S IAI 


\section{Introduction}

The predisposition of financial economists is to view the corporate pension plan primarily as a venicle for tax-sheltered saving. In the Uniced States, the corporate pension plan may also be viewed as a vehicle for gaming against the interests of the third party insurer of pension benefits, the Pension Benefit Guarantee Corporation (PBGC). Financial economists recognize, of course, that pension benefits also represent an integral part of the worker's total compensation package. Yet because of their primary interest in tax and related issues, financial economists typically invoke the simplest and the most analytically tractable model of the labour market. This is the spot model, in which workers are tied to the firm but for a single perrod. As a result, workers must receive total compensation - cash wages plus accruing pension benefits - equal to the value of their marginal product in each and every period. Black (1980) and Tepper (1981), for example, invoke the spot model to derive their well-known funding and asset allocation theorems, and Sharpe (1976) uses it in his analysis of strategic issues pertinent to the insurance provided Dy the PBGC.

Somewhat ironically, researchers have now begun to realize that corporate pension plans provide a perhaps unique opportunity to assess the empirical validity of the spot model. Feldstein-Seligman (1981), BulowScholes (1983) and Pesando (1984a) have noted the presence of discontinuities in most pension benefit formulas, and conjectured that these discontinuities make it unlikely that a worker's casn wage will internalize the value of the worker's accruing pension benefits on a period-by-period basis. These discontinuities occur at the dates that (1) the worker's benefits vest (i.e., the worker becomes legally entitled to a nonforfeitable benefit under the 
terms of the plan) and (2) the worker qualifies for an early retirement benefit.

This paper undertakes two main tasks. The first is to illustrate the time path of a worker's wage if the spot model is valid and the pension plan to which the worker belongs has typical vesting and early retirement provisions. Under any reasonable assumption about the time path of the (nonobservable) value of the worker's marginal product, the implied discontinuities in tile worker's cash wage are so abrupt that the spot model is severely discredited. The second task is to calculate the pension benefits actually accrued by workers on and around the dates that they qualify tor vested or for early retirement benefits, using data from five pension plans in Canada. These calculations indicate that discrete jumps in a worker's pension wealth (and thus in the worker's accruing pension benefits) do occur, especially at the date that the worker qualifies for an early retirement benefit. The paper then assesses tne relevance of these findings for the underfunding puzzle, for the measurement of pension liabilities, and for the recapture of surplus assets from overfunded plans. A summary section completes the paper.

2. The Time Path of Cash Wages Under the Spot Model in a Pension Plan With "Cliff" Vesting and Early Retirement Provisions

Most members of corporate pension plans in Canada and the United States belong to final earnings plans. 1 In a typical plan, the member receives - for each year of service - pension benefit equal to $\underline{x}$ percent of his (her) earnings during the latest $\underline{y}$ years of his (her) employment. In both Canada 
and the United States, "cliff" vesting provisions are common.2 Unoer these provisions, a worker becomes 100\% vested after meeting a service or an age and service requirement. More than $50 \%$ of plan members are in plans in which the worker must complete 10 years of service before the worker become legally entitled to a nonforfeitable pension benefit. Virtually all plan members in Canada, and the vast majority in the United States, 3 belong to plans in which workers may opt to retire in advance of their normal retirement ages. The most common condition that a worker must meet to qualify for an early retirement benefit is the attainment of age 55 and the completion of 10 years of service. The benefit provided on early retirement is typically the pension earned up to the date of early retirement based on the benefit formula of the plan, reduced by a specified amount. A common provision is that the pension benefit be reduced by $1 / 4$ of $1 \%$ for each month that early retirement precedes the normal retirement age, which is usually 65. In spite of the reduction formula, the early retirement benefit is more than "actuarially fair". For a terminating worker, the present value of the expected stream of payments under the early retirement provision exceeds the present value of the expectea stream of payments under the normal retirement provision. In effect, early retirement is subsidized. This subsidy is most apparent in the many plans which provide for unreduced early retirement benefits if the member meets a more stringent age and service requirement.

If the features of the pension plan are known, the time path of the cash wages that must be paid to a worker under the spot model is readily determined. First, one postulates a hypothetical time path of the (nonobservable) value of the worker's marginal product. One then calculates the cash wage that satisfies the conaition that the worker's total compensation, inclusive of the pension benefit, equals the value of the worker's marginal 
product in each period. Of particular interest are discontinuities in the wage path that may exist around the dates that the worker's benefits vest or the worker qualifies for an early retirement beneift. If these discontinuities are large, they are likely to have no empirical counterpart. If so, they would provide prima facie evidence against the spot model.

Illustrative wage paths are shown in Tables 1 and $1 A$ for a male worker who belongs to a "generous" and a "less generous" final earnings plan. In the generous plan, the pension benefit is equal to $2 \%$ of the worker's average earnings during the past 5 years for each year of service. In the less generous plan, the corresponding benefit is only $1 \%$. These figures bracket the range of benefits provided by corporate pension plans in Canada. In all other dimensions, the plans are the same. The pension benefits is nominal; that is, the annuities due under the terms of the plan receive no inflation protection. Benefits vest in full once the worker has completed ten years service. If the worker quits the firm prior to this time, he receives no pension benefit at a11. An employee who reaches age 55 and has completed ten years of service becomes eligible for an early retirement benefit. The early retirement pension equals the accrued pension that the worker would otherwise receive at the normal retirement age of 65 , less $3 \%$ for each year by which his actual retirement age precedes age 65. If the worker retires at age 55, he receives $70 \%$ of the pension that wuld otherwise commence at age 65 ; at age $56,73 \%$; and so on. An employee whose benefits have vested, but who quits the firm without meeting both of the requirements for early retirement, is entitled only to a deferred pension commencing at the normal retirement age. 4

To calculate the wage path under the spot model, one must make assumptions regarding the tenure at the firm of the representative emplayee as well as the economic environment. The robustness across different sets of 
assumptions can be readily assessed. In Tables 1 and $1 A$, a representative male worker is assumed to begin work (and join the pension plan) when he is age 30 . The assumed inflation rate is $9 \%$ and the nominal interest rate is 12\%. (These assumptions accord roughly with market conditions in Canada in 1982, which is the year for which actual benefit accruals are calculated in the next section of the paper.) The nominal value of the worker's marginal product is assumed to grow at an annual rate of $11 \%$. Most large firms in Canada and the United States have granted ad hoc cost-of-living adjustments to retired workers, and one of the plans examined later in this study provides for fully indexed pensions. It is thus useful to examine the case in which the annuities due under the terms of the plan are real. Following Pesando (1984b), the risk-free real interest rate used to value these annuities is set equal to one percent.

The time paths of real wages, for both plans, are shown for the case in which pension benefits are purely nominal and for the case in which pension benefits are fully indexed for inflation. The discontinuity associated with the cliff vesting rule is noticeable, especially when the pension benefit is real. However, the discontinuity is not dramatic. Even when the plan is generous and the pension benefit is real, a real wage reduction of slightly less than $10 \%$ in the employee's 10 th year of service is sufficient to equalize the worker's total compensation with the value of his marginal product. If a "looser" restriction is associated with the spot model, such as the equality of total compensation and the value of the worker's marginal product over a two- or three-year horizon, this discontinuity would be smaller and of even less consequence.

By contrast, the discontinuity which occurs at the date the worker qualifies for the early retirement benefit is dramatic. Even when the pension 
benefit is nominal and the plan is less generous, the worker's real wage must fall by almost $50 \%$ in the year in which he qualifies for the early retirement benefit. 5 If the pension benefit is real, under either plan, the worker's cash wage in the year that ne qualifies for the benefit must be negative. The worker must actually make a cash payment to his employer! Declines in a worker's cash wage of this order of magnitude have no empirical counterpart, even if a "looser" restriction is associated with the spot model. The real wages required by the spot model vegin to fluctuate sharply after the worker has qualified for the early retirement benefit. These fluctuations simply reflect the 5-year averaging in the benefit formula, together with the dramatic reduction in the worker's cash wage in the year that he qualifies for the early retirement benefit. In addition, real wages grow on average more rapidly after the worker has qualified for the early retirement benefit. This more rapid growth reflects the compensation needed to offset the decline in the value of the early retirement option each year that the worker chooses not to exercise it. 6

The size of the discontinuities associated with cliff vesting and early retirement provisions in different economic environments is also worthy of note. In Table 2 , the interest rate, intlation rate and growth rate of the worker's marginal product are first set equal to $4 \%, 1 \%$ and $3 \%$, and then to $6 \%, 3 \%$ and $5 \%$. In the case in which pension benefits are nominal, which is the one illustrated in Table 2, the discontinuity associated with the cliff vesting rule assumes much greater importance. Real wages must decline by $58 \%$ on the vesting date if the interest rate is $4 \%$, and by $44 \%$ if the interest rate is $6 \%$. Note, however, that the discontinuities associated with the early retirement provisions are still greater. Real wages must decline by $65 \%$ if the interest rate is $4 \%$, and by $75 \%$ if the interest rate is $6 \%$. 
To sum up, cliff vesting rules provide what is the more apparent discontinuity in a worker's accrual of pension benefits. Prior to the date that a worker's benefits vest, the worker's pension benefit is worth nothing according to the spot model. Yet when nominal interest rates are at doubledigit levels, the discontinuity associated with cliff vesting rules is not likely to be large. By contrast, the discontinuity associated with early retirement provisions is dramatic in both the high and the low interest rate environments.

\section{Discontinuities in the Accrual of Pension Benefits: Some Evidence}

The pension benefits actually accrued by plan members represent a potentially important source of evidence regarding the empirical valiaity of the spot model. Suppose, for example, that a discrete jump in pension wealth occurs at the date that a worker satisfies a delayed vesting rule or qualifies for an early retirement benefits. Unless there is a commensurate wage reduction, a discrete jump will also occur in the worker's total compensation. If this is large, it is unlikely to correspond to a like increase in the (nonobservable) value of the worker's marginal product.

This insight is not new. Feldstein-Seligman (1981), Bulow-Scholes (1983) and Pesando (1984a) have conjectured that discontinuities associated with delayed vesting rules and/or early retirement benefits make it unlikely that cash wages will internalize accruing pension benefits on a year-to-year basis. By implication, all have suggested that a study of pension benefit accruals would bear usefully on the empirical validity of the spot model. Wise and Kotlikoff (1984) have actually undertaken such an investigation. 
Unfortunately, Wise and Kotlikoff $(W-K)$ do not have data that would permit them to link the cash wages paid to an individual worker to the specifics of the pension plan to which the worker belongs. W-K, like Lazear (1983) before them, are forced to postulate hypothetical wage paths for a representative worker. W-K thus calculate a worker's pension wealth and benefit accruals on the assumption that the cash wages paid to a worker are independent of the features of the pension plan to which the worker belongs. As $W-K$ readily acknowledge, this is an unsatisfactory assumption if the purpose of the research is to evaluate the empirical validity of the spot model.

In order to monitor their pension costs, most firms conduct actuarial valuations of their plans on a periodic basis, of ten annually. To conduct these valuations, firms must compile data on a worker's sex, wage history, age and years of service. In effect, firms must compile the data necessary to calculate the value of the worker's pension wealth at each point in time, and thus the value of the benefit that he accrues between two points in time. Unfortunately, actuaries typically do not calculate the worker's pension wealth in the manner required by the spot model. The spot model requires that a worker's pension wealth (and the firm's pension liabilities) be calculated on a wind-up basis; that is, as if the plan were terminated and the sponsoring firm purchased the annuities necessary to discharge its pension obligations. It is thus necessary to calculate pension wealth and benefit accruals on a wind-up basis, using the data compiled in the normal course of these actuarial valuations.

GBB Associates Ltd., an employee benefit consulting firm, has made such data available for a sample of five Canadian pension plans. From these data, one is able to calculate the pension wealth at the end of 1981 and 1982, and thus the pension benefit accrued in 1982, for a representative male worker in 
each age or service cohort. The major provisions of each of the five plans are detailed in Table 3. All of the plans link the member's pension benefit to his earnings during his final years of employment, all are integrated with government social security plans, and all have delayed vesting and early retirement provisions. One plan is unusual in that it provides during the member's retirement for the full indexing of his pension benefits to movements in the consumer price index. Two of the plans have a policy of providing ad hoc cost-of-living adjustments to pensions in pay, in spite of the fact that the contractual benefits provided by the plans are purely nominal. In this regard, they are representative of the majority of large plans in both Canada and the United States. 7

The objective is to calculate the pension benefit accrued by a representative member of each age or service cohort, with attention to any discontinuities which occur at the dates that the cohort meets the vesting requirement or qualifies for an early retirement benefit. When the eligibility criterion is age or years of service, one can identify the exact age or service cohort that is just qualifying for the benefit. If the vesting requirement is 10 years of service, for example, then it is the benefit accrued by a representative member of the 10-year service cohort that will reflect any discontinuity associated with this delayed vesting rule. In order to calculate this benefit accrual, one must postulate an age for the representative member of the service cohort. One can, however, really determine the robustness of the calculation across the feasible range of age distributions, guided by the cross-tabulations described below.

Complications do arise when the eligibility condition consists of both age and years of service. Most of the plans, for example, provide an early retirement benefit when the member has attained age 55 and completed 10 years 
of service. Ideally, one would like to solve this problem by working with data on individual workers or with data on cohorts with a fixed age and a fixed number of years of service. Unfortunately, such data are not available. For each plan, cross-tabulations on age and years of service are available, but only for 5-year groupings. For example, one can identify for the cohort aged 48 to 52 the fraction that have 8 to 12 years of service, 13 to 17 years of service, and so on. Inspection of these cross-tabulations indicates that virtually all plan members who have attained age 55 have completed 10 or more years of service. One is thus comfortable in assuming that it is the 55-year age cohort that is just qualifying for the early retirement benefit. To calculate the benefit accrued by a representative member of this age cohort, one must choose a representative number of years of service. Again, it is straightforward to calculate the robustness of any discontinuity so identified with regard to this assumption.

\section{Early Retirement Provisions}

The wage paths illustrated in Tables $1, I A$ and 2 highlight the potential importance of early retirement provisions. These are examined first in the present section. One plan in the sample provides for early retirement at age 50 if the plan member has completed 25 years of service. The others provide for early retirement at age 55 if the member has completed 10 years of service. In Table 4, the benefits accrued by a representative member of each service cohort are presented for the first plan. Inspection of the relevant cross-tabulation indicated that the majority of those completing 25 years of service had attained age 50, and thus that the majority of the members of this service cohort were just qualifying for the early retirement benefit. To the 
extent that there are workers who complete 25 years of service without attaining age 50, the benefit accrued by a representative member of this cohort is overstated. By implication, the benefit accrued by a representative meniber of a cohort completing 26 or more years of service is understated, since some members of these cohorts are just qualifying for the early retirement benefit. In Table 5, benefit accruals are reported by age cohort for the remaining four plans. As previously noted, virtually all members who attain age 55 have completed 10 years of service.

The interest rate used to calculate the present value of nominal pension benefits is 12 percent. This is equal to the interest rate prevailing at year-end 1982 on long-term Government of Canada bonds. Its use is tantamount to assuming that workers in these plans treat their accruing pension benefits as risk free. Note that no turnover assumptions are necessary when pension wealth and benefit accruals are calculated on a wind-up basis. The calculations mirror those sketched in footnote 5, except that explicit consideration is given to integration provisions. Under these provisions, pension benefits provided by a private plan are typically reduced by some fraction of the benefits provided by public pension programs (the Canada/Quebec Pension Plan and 0ld Age Security). 8

For all five plans, the discontinuity in the accrual of pension benefits that occurs when the worker qualifies for an early retirement benefit is dramatic. In the first plan, where early retirement is available at age 50, the pension benefit accrued by a representative member of the 25-year service cohort is equal to 140 percent of his cash wage. For the other four plans, where early retirement is available at age 55, the pension benefit accrued by a representative member of the 55-year old cohort ranges from 85 percent to 122 percent of his cash wage. These latter figures are even greater if 
allowance is made, where appropriate, for the ad hoc cost-of-living adjustments made by plan sponsors, or for the fact that at least some plan members who attain age 55 also qualify for unreduced early retirement benefits. In Plan 2, the benefit accrued by the representative member of the 55-year old cohort rises from 122 percent to 199 percent of his cash wage when consideration is given to the plan sponsor's announced policy of making costof-living adjustments to offset one-half of the impact of inflation. In Plan 4 , members qualify for an unreduced early retirement benefit after they have attained age 55 and completed 30 years of service. If a member of this 55year old cohort has completed 30 years of service, as one-half of them have, the benefit he accrues in this year of eligibility is actually 249 percent of his cash wage.

To sum up, the results reported in Tables 4 and 5 indicate that wages do not internalize the discontinuity associated with the existence of early retirement provisions. ${ }^{9}$ As previously noted, early retirement provisions are prevalent, and they appear to represent a quantitatively important discontinuity in the accrual of pension benefits.

\section{Delayed Vesting Rules}

Due in large part to the high level of nominal interest rates prevailing in $1982,{ }^{10}$ discontinuities associated with delayed vesting rules are not large for the members of the sample plans. The benefits accrued at and around the date at which an age or service cohort satisfies the vesting requirement are presented in Table 6. Not surprisingly, in light of the level of interest rates, nominal pension benefits accrued 20 or more years prior to the date at which payments are scheduled to commence have relatively little value. For 
Plan One, the worker whose benefits have vested is entitled to a deferred annuity which is fixed in real terms after the worker has attained the normal retirement age of 65 . The benefit accrued by a member of this plan who attains age 45 , if he has completed 20 years of service, is equal to 29.9 percent of his cash wage. The results for Plans 2 and 3 , however, are more representative. At the date that a representative employee meets the vesting standard, he receives a benefit equal to about $4 \%$ of his cash wage. Plans 4 and 5 are contributory, so that both the firm and the employee make contributions. As a result, the figures reported in Table 6 seriously overstate the benefits that the worker actually accrues on the date that his benefits vest. This is because the calculations ignore the fact that a terminated worker whose benefits have not vested will receive back the accumulated value of his own contributions. Indeed, crude calculations suggest that the accumulated value of the member's own contributions may well exceed the present value of the deferred annuity to which the vested employee is entitled. If so, there is no increase in the worker's pension wealth on the date that the worker's benefits vest.

\section{Implications of These Preliminary Findings}

The results presented in the two preceding sections serve to discredit the spot model. Indeed, the very existence of early retirement provisions is prima facie evidence against this model, given the extraordinary reduction in a worker's cash wage that is necessary to internalize this benefit in the year in which the worker qualifies for it. 
There is, of course, no paucity of alternatives to the spot model. Following Becker (1964), labour economists have devoted considerable attention to the complications that arise when workers have firm-specific human capital. of particular interest in the present context, however, are equilibrium models which focus on market-clearing in incentive-oriented, lifetime contracts. Only large firms tend to sponsor defined benefit plans, and their size may serve in the present context as a proxy for their expected longevity. Smaller firms, where the probability of failure is high, may find it difficult to enter into lifetime contracts with their employees.

In a series of papers, Lazear (1979, 1981, 1983) argues that workers and firms are likely to enter into implicit contracts which provide for older workers to receive total compensation in excess of the value of their marginal product, and conversely for younger workers. The purpose of these incentiveoriented, lifetime contracts is to increase productivity and to discourage shirking. Salop and Salop (1976) argue that the deferral of part of a worker's total compensation to the worker's later years serves, through selfselection, to screen out workers who are likely to quit, and thus to reduce the firm's training costs. Medoff and Abraham (1980, 1981) have provided evidence, drawn from the personnel files of major corporations in the United States, to suggest that more experienced workers do receive total compensation in excess of that which would be projected on the basis of the performance evaluations conducted by their immediate supervisors.

The purpose of this section of the paper is to assess the implications of the rejection of the spot model for three topical issues that are of concern to financial economists. These are: (1) the optimal degree of pension funding; (2) the measurement of a firm's pension liabilities; and (3) the controversy surrounding the recent acceleration in the termination of overfunded plans with the reversion of the surplus assets to the employer. 


\section{The Optimal Degree of Pension Funding}

The tax treatment of pension plans in both Canada and the United States permits pension funds to earn the before-tax rate of return. If there is no probability that the sponsoring firm will go bankrupt, its optimal strategy is to fully fund the plan (Black (1980), Tepper (1981)). In the United States, where the PBGC is a third party insurer of pension benefits, a different extreme solution may prove optimal. This is to fund the plan to the minimum extent permitted by regulation, while investing in only the most risky assets. This strategy maximizes the value of the put option held against the PBGC (Sharpe (1976), Harrison and Sharpe (1983)). In Canada, plan termination insurance exists only in Ontario, and the liability of the sponsoring firm extends to $100 \%$ of its equity in the event of a claim on the province's Guarantee Fund. There is no opportunity for strategic behaviour against the third party insurer of pension benefits that is comparable to the one that exists in the United States. 11

In both Canada and the United States, there is evidence to suggest that pension plans are often underfunded, at least if consideration is given to implicit pension liabilities. ${ }^{12}$ Equally important, there is no evidence that pension plans are overfunded to the maximum extent permitted by law. The obvious question is whether this failure to exploit fully the tax shelter provided corporate pension plans is evidence of non-optimizing behaviour on the part of firms.

Among the first financial economists to stress the incentive effects of pensions is Logue (1979). In the present context, he argues that unfunded pension liabilities may have an important incentive effect on management, thus reducing monitoring costs to the firm's non-pension creditors as well as 
promoting effort. In a recent paper, Ippolito (1985a) sets forth a similar hypothesis, that underfunded pension plans represent a means by which a firm can bond its unionized work force and thus pre-empt behaviour that might threaten the firm's long-term viability. The emphasis on the role of a unionized work force as an unsecured bondholder is tied to the empirical observation that flat benefit or pattern plans, which exist only in the union sector, are typically the least well funded of pension plans.

In general, once the spot model with its exclusive focus on a single period is abandoned, it is possible to construct models which may provide a more credible explanation of the underfunding puzzle. Although a critical review of such alternatives is beyond the scope of the present paper, one general point raised by Ippolito merits continued emphasis. Unless a large number of firms are not acting rationally, there must be some advantages to shareholders which offset the tax disadvantages of maintaining an underfunded plan. To search for such advantages, it seems fruitful - both analytically and empirically - to abandon the restrictive framework of the spot model.

\section{The Measurement of Pension Liabilities}

Bulow (1982) is the first to emphasize the fact that the wind-up measure of a firm's pension liabilities is tied to the spot model of the labour market. If neither the employer nor the worker looks beyond the current period when the worker's total compensation is being determined, then the appropriate measure of the firm's pension liabilities can have no forwardlooking component. Under the wind-up measure, the pension liabilities of an on-going firm equal the value of the annuities that the firm would have to buy in order to discharge its obligations if the pension plan were terminated or 
if its workers were dismissed. In actuarial terms, this involves the use of the accrued benefit method without salary projection. Whenever economists use this method to calculate the pension liabilities of the firm, they are implicitly (if not explicitly) invoking the spot model of the labour market, at least if workers are presumed to negotiate individually with the firm. 13 Such is the case, for example, when Feldstein and Morck (1983) use the wind-up measure in their study of the capitalization of unfunded pension liabilities into share prices.

Any evidence which casts doubt on the validity of the spot model thus casts doubt on the usefulness of the wind-up measure of a firm's pension liabilities. The rejection of the spot model does not, of course, necessarily point to a unique alternative to the wind-up measure. In a recent paper (Pesando (1985)), I argue that the wage/age profiles of members of final earnings plans suggest that the wind-up measure is likely to understate a firm's true pension liabilities. Whether the accrued benefit method with salary projection or a projected benefit method is the preferred alternative is not, however, readily established.

clearly, the measurement of pension liabilities is central to many pension issues that are of interest to financial economists. It should also be emphasized, however, that the wind-up measure becomes an issue in perhaps more subtle ways. When interpreting tests of the impact of unexpected inflation on shareholder wealth, such as those conducted by French, Ruback and Schwert (1983), it is important to determine whether pension liabilities are purely nominal as implied by the wind-up measure, or whether they have a substantial real component. The fact that most large firms grant ad hoc costof-living adjustments to retirees, in spite of the fact that the pensions legally due under the terms of the plan are purely nominal, suggests the 
existence of a real component to the firm's pension liabilities. So, too, does the evidence reported in Pesando (1985), which suggests that older workers receive wage increases that do not internalize the increasing value of their accruing pension benefits.

\section{The Termination of Overfunded Plans with Asset Reversions to the Employer}

The termination of an overfunded pension plan, with the reversion of surplus assets to the employer, is now a contentious and highly visible issue in the United States. In October of 1984, Edward R. Roybal, chairman of the House Select Committee on Aging, proposed comprehensive legislation (H.R. 6404) designed to discourage plan terminations that result in asset reversions. If the termination does not meet a business necessity test, he proposes that excess assets would revert not to the employer, but to workers and retirees. In Ontario, the sponsor of an ongoing plan can request the refund of a plan surplus, so long as a amount equal to two years of the employer's current service cost is left in the plan. This practice, too, is controversial. Interested parties in Ontario continue to debate whether the shareholders of the firm or the members of the plan have the property rights to surplus plan assets. In Quebec, by way of contrast, no refund of surplus assets is permitted for ongoing plans.

How does evidence regarding the validity of the spot model bear on the present controversy? The answer is tied to the recognition that surplus assets are calculated using the wind-up measure of the firm's pension liabilities. As noted repeatedly, this is a valid measure if and only if the spot model is supported empirically; that is, if workers actually accept compensation packages under the premise that their employment might be severed 
at any time. If the spot model were correct, workers would value their pension wealth on a wind-up basis and grant the appropriate wage concessions. If the spot model is not true, then workers presumably grant wage concessions in excess of those implied by the spot model, in return for pension benefits which exceed those implied by the wind-up measure.

If the spot model were valid and thus pension liabilities were appropriately valued on a wind-up basis, then the termination of an overfunded plan with the reversion of excess assets to the employer would impose no windfall losses on employees. Because the empirical validity of the spot model is very much in doubt, the possibility does exist that employees suffer windfall losses in these overfunded terminations, at least if they are not appropriately compensated in other ways. Yet an on-going firm which unilaterally severs such an implicit contract would also suffer costs, in the form of its inability to enter into such contracts in the future. If the termination occurs in a division which is being spun off by a parent, or more generally - where the goodwill of the affected workers is of less concern to the corporation, the probability that the affected workers suffer windfall losses presumably rises. A detailed examination of the case for a legislative initiative is beyond the scope of the present paper. Such an examination would, however, usefully proceed along the lines sketched above.

\section{Summary and Conclusion}

This paper provides evidence which discredits the spot model of the labour market. Labour economists, with their interest in firm-specific human capital and incentive-oriented compensation arrangements, might find it surprising that financial economists have - in effect - placed so much 
reliance on the spot model. Yet, for many purposes, this assumption might have remained satisfactory if the predictions of the resulting models of financial behaviour were supported by the data.

In this light, it is important to note that empirical studies have provided only modest support for the model of the corporate pension plan favored by financial economists; that is, as an integrated part of the corporation's overall financial strategy. Friedman (1983) concludes that there are systemmatic differences in the way in which corporations manage their pension funds, but that these differences are often inconsistent with hypotheses put forward in the finance literature. He observes, for example, that less profitable corporations with more volatile earnings hold less - not more - common stock in their pension funds. He finds no significant relationship between the degree of funding of the pension plan and the allocation of assets within the fund. In short, Friedman finds no evidence to support the extremal solutions (full funding/all bonds or minimum funding/all stocks) that have been put forward by financial theorists. Bodie et al. (1984) do find evidence that the level of pension funding is linked positively to the corporation's long-run profitability. Yet they conclude, on balance, that tax considerations and the put option held by the plan sponsor against the PBGC "do not leave strong traces" in the data.

The rejection of the spot model implies that pension plans do provide incentive effects. The suggestion must be that richer, incentive-oriented models of the labour market might shed light on a number of issues that puzzle financial economists, including the fact that plan sponsors do not fully utilize the tax shelter represented by the corporate pension plan. In addition, the empirical validity of such models is central to the resolution of one of the most fundamental of problems, that of obtaining the most appropriate measure of the pension liabilities of the firm. 


\section{Footnotes}

1. For details on pension benefit formulas in Canada, both by number of plans and plan membership, see Statistics Canada (1979). Detailed information on pension plans in the United States may be found in Kotlikoff and Smith (1983).

2. In the United States, ERISA requires that vesting provisions be at least as liberal as the following. A worker who completes 10 years of service must be at least $50 \%$ vested, and those who are only $50 \%$ vested must receive a 10\% annual increase in their vested rights until full vesting is achieved. In Canada, the minimum vesting provision established by statute is 10 years of service plus attainment of age 45 . This is likely to be liberalized in the near future.

3. In Canada, 96\% of plan members in 1978 were in plans with early retirement provisions. In the United States, the corresponding figure in 1977 was $82 \%$. See the references in footnote one for further details.

4. This is the usual, but not universal, practice in Canada. A worker who has met the service requirement for early retirement, but who quits the firm before meeting the age requirement, is entitled only to the benefit due at the normal retirement age unless the plan explicitly provides otherwise. The exact extent of such provisions has not been clearly established. None of the five plans examined in this paper contain the provision. Richard Ippolito of the U.S. Department of Labor has provided me with the Summary Plan Descriptions of 25 plans in the United States. 
In virtually all of these plans, terminated vested workers can qualify for early retirement benefits on the same terms as employees who actually retire early. A terminated vested worker who has met the service requirement subsequently qualifies for an early retirement benefit when the worker meets the age requirement. The worker thus benefits from any subsidized early retirement factors that apply to still active employees. In this case, which is the one illustrated by Wise and Kotlikoff (1984), the existence of a subsidized early retirement benefit creates a discontinuity at the date that the worker meets the service requirement for this benefit, so long as the worker has met (or is just meeting) the vesting requirement. In general, the myriad of pension plan provisions in both Canada and the United States suggests that discontinuities in benefit accruals - and thus in the wage path under the spot model - are likely to have important plan-specific components.

5. Let $\bar{E}(55)$ denote the worker's average earnings during the past 5 years, inclusive of his 55 th year. Let $d(55)$ be the discount applied via the reduction formula for early retirement. Let $A(r, 55)$ be the present value at the nominal interest rate $r$ of a life annuity commencing at age 55. If the 55-year old worker has completed 25 years of service and if the nominal pension benefit is $2 \%$ of final average earnings for each year of service, then the worker's pension wealth at age 55 is:

$$
W(55)=25 * .02 * d(55) \star \bar{E}(55) * A(r, 55)
$$

A year earlier when the worker was 54, and had not yet qualified for the early retirement benefit, his pension wealth is readily calculated. 
Assume, for simplicity, that if a worker dies between the date of his termination and the date that he would begin to receive his deferred pension, his estate receives a death benefit equal to the then present value of the deferred annuity. One can then treat the worker as if he would live with certainty to the age at which he begins to draw his life annuity, and his pension wealth is simply:

$$
W(54)=24 * .02 * \bar{E}(54) \star A(r, 65) *(1+r)^{-11}
$$

Thus the benefit B that the worker accrues in his 55 th year is:

$$
B(55)=W(55)-(1+r) * W(54)
$$

Since the value of $W(54)$ rises at the interest rate $r$ even if the worker leaves the firm, it is not a part of the pension benefit that he accrues during his 55 th year.

One can solve (F1), (F2), and (F3) for the worker's cash wage $w$ in his 55 th year under the spot model of the labor market. The sum of this wage and the worker's accruing pension benefit must equal the value of his marginal product (VMP):

$$
W(55)+B(55)=\operatorname{VMP}(55)
$$

If the worker's pension benefit is real and if the real interest rate is $i$, then $(F 1),(F 2)$ and $(F 3)$ become: 


$$
\begin{array}{lll}
W(55)=25 * .02 * d(55) * \bar{E}(55) \star A(i, 55) & F(1)^{\prime} \\
W(54)=24 \star .02 * \bar{E}(54) * A(i, 65) \star(1+r)-11 & F(2)^{\prime} \\
B(55)=W(55)-(1+r) \star W(54) & F(3)^{\prime}
\end{array}
$$

Note that $(F 2)^{\prime}$ and $(F 3)^{\prime}$ imply that if the worker leaves the firm before qualifying for his early retirement benefit, then the real value of $h$ is pension benefit is eroded by inflation until he begins to draw his pension at the normal retirement age of 65 . This is the case for the one plan in the sample that provides for fully indexed annuities.

6. Bulow (1981) points out that the decline in the value of this option provides the plan sponsor with a method of reducing the total compensation of older workers without reducing their salary. Clark and McDermed (1985) emphasize that the cash wages paid to a worker must under the spot model - accelerate after the date that the worker become eligible for a normal retirement benefit, assuming that the pension is not actuarially increased if the worker elects to defer retirement and thus its receipt. They provide some evidence from the Retirement History Study that this is the case, thus providing some support for the spot mode 1 .

7. See Pesando (1984a) and Allen, Clark and Sumner (1984) for evidence regarding the payment of ad hoc cost-of-living adjustments in Canada and the United States, respectively.

8. One first calculates the worker's pension wealth, which is the discounted (by interest and mortality) payments due him under the terms of the plan. 
One then calculates the present value of the reduction in these payments that occurs as a result of the integration provisions. To do this calculation, I assume that public pension benefits will remain constant in real terms. The integration offset is then subtracted from the worker's private pension wealth, and benefit accruals are then derived from the net pension wealth figures. For a more elegant treatment of integration provisions in a contingent claims framework, see Merton, Bodie and Marcus (1984).

9. The only qualification to this conclusion is linked to Plan 5, and it does not appear to be important. About 20 percent of the 25 -year service cohort have not yet attained age 50 and thus have not yet qualified for the early retirement benefit. These individuals do not, under the spot model, require large wage reductions in their 25 th service year. For the majority of workers who are completing their 25 th service year, a significant wage reduction is required under the spot model. The fact that the average salary of this service cohort rose by 13.4 percent in 1982 effectively rules out the possibility that dramatic wage reductions for the qualifying group are being masked by the appropriate (to the value of their marginal product) wage increases of the non-qualifying group. For this to be the case, the wage increases granted the nonqualifying group would have to be so large as to be unfeasible on a prima facie basis.

10. The worker's pension wealth equals the present value of the expected stream of payments that the worker would receive if the worker quit the firm. Unanticipated fluctuations in interest rates thus produce 
corresponding fluctuations in the value of a worker's pension wealth. An increase in interest rates, for example, reduces the cost of purchasing the annuity to which the worker is entitled, thereby reducing the worker's pension wealth.

11. For a discussion of termination insurance in Ontario, see Pesando (1982). In the United States, a number of bills have been introduced in the House and the Senate (for example, H.R. 3930 and S.1227), to limit the ability of ongoing firms to impose claims on the PBGC.

12. For a discussion of the funded status of pension plans in the United States, with particular attention to the role of implicit pension liabilities, see Ippolito (1985b). For an analysis of the funded status of pension plans in Canada, see Ezra (1983). With the recent rally in the stock market and the continuing high level of long-term interest rates, most plans are fully funded on a wind-up basis.

13. Bulow-Landsman (1983) draw attention to the possibility that the wind-up measure of pension liabilities may nonetheless be valid if the tradeoff between wages and accruing pension benefits takes place at the level of the employee group as a whole. If an unusually large number of employees qualifies for an early retirement benefit, this may be offset by unusually large wage concessions from the employee group as a whole. This type of behaviour is, one might conjecture, more likely to characterize the total compensation packages negotiated formally in the union sector. Among non-unionized employees, where earnings-related pension plans are typically found, the a prior case is less convincing. 


\section{References}

Allan, Steven G., Clark, Robert L. and Daniel A. Sumner (1984). "PostRetirement Adjustments of Pension Benefits". National Bureau of Economic Research, Working Paper No. 1364, June.

Becker, Gary S. (1964). Human Capital: A Theoreticaland Empirical Analys is with Special Reference to Education. (New York: Columbia University Press.)

Black, Fischer (1980). "The Tax Consequences of Long Run Pension Policy". Financial Analysts Journal 36 (July-August): 3-10.

Bodie, Zvi, Light, Jay, Morck, Randall and Robert A. Taggart, Jr. (1984). "Funding and Asset Allocation in Corporate Pension Plans: An Empirical Investigation". National Bureau of Economic Research, Working Paper No. 1315, March.

Bulow, Jeremy (1981). "Early Retirement Pension Benefits". NBER Working Paper No. 654, April.

(1982). "What are Corporate Pension Liabilities?" Quarterly Journal of Economics 97 (August): $435-52$. and Wayne Landsman (1983). "The Relationship Between Wages and Benefits". Paper presented at National Bureau of Economic Research Conference on Pensions, Labor and Individual Choice, Dorado Beach, Puerto Rico. and Myron Scholes (1983). "Who Owns the Assets in a Defined-Benefit Pension Plan?". In Zvi Bodie and John Shoven, eds., Financial Aspects of the United States Pension System (Chicago: University of Chicago Press). Clark, Robert and Ann McDermed (1985). "Earnings and Pension Compensation, the Effect of Eligibility". Mimeograph, North Carolina State University. 
Ezra, Don (1983). The Struggle for Pension Fund Wealth (Toronto: Pagurian Press Limited).

Feldstein, Martin and Randall Morck (1983). "Pension Funding Decisions, Interest Rate Assumptions, and Share Prices". In Z. Bodie and J.Shoven, eds. Financial Aspects of the United States Pension System (Chicago: University of Chicago Press). and Stephanie Seligman (1981). "Pension Funding, Share Prices and National Savings". Journal of Finance 35 (September): 801-24. French, Kenneth R., Ruback, Richard S. and G. William Schwert (1983). "Effects of Nominal Contracting on Stock Returns". Journal of Political Economy 91: No. 1 (February): 70-96.

Friedman, Benjamin (1983). "Pension Funding, Pension Asset Allocation and Corporation Finance: Evidence from Individual Company Data". In Z. Bodie and J. Shovens, eds. Financial Aspects of the United States Pension System (Chicago: University of Chicago Press). Harrison, J. Michael and William Sharpe (1983). "Optimal Funding and Asset Allocation Rules for Defined-Benefit Pension Plans". In Z. Bodie and J. Shovens, eds. Financial Aspects of the United States Pension System (Chicago: University of Chicago Press). Ippolito, Richard (1985a). "The Economic Function of Underfunded Pension Plans". Journal of Law and Economics, XXVIII: No.3 (October): 611-652. (1985b). "The Labor Contract and Real Economic Pension Liabilities". American Economic Review, forthcoming.

Kotlikoff, Laurence and Daniel Smith (1983). Pensions in the American

Economy. (Chicago: University of Chicago Press).

Lazear, Edward (1981). "Agency, Earning Profiles, Productivity and Hours Restrictions", American Economic Review 71: No. 4 (September): 6066210. 
(1983). "Pensions as Severance Pay". In Z. Bodie and J. Shoven,

eds. Financial Aspects of the United States Pension System (Chicago:

University of Chicago Press).

(1979). "Why is There Mandatory Retirement?" Journal of Political

Economy 87: No. 5 (December 1979): 1261-84.

Logue, Dennis (1979). Legislative Influence on Corporate Pension Plans.

(Washington, D.C.: American Enterprise Institute).

Medoff, J. and K. Abraham (1981). "Are Those Paid More Really More

Productive?". Journal of Human Resources XVI No. 2 (Spring): 186-216.

(1980). "Experience, Performance and Earnings". Quarterly Journal

of Economics XCV: No. 4 (December): 703-736.

Pesando, James (1982). "Investment Risk, Bankruptcy Risk and Pension Reform

in Canada". Journal of Finance, 37: No.3 (June: 341-349.

(1984a). "Employee Valuation of Pension Claims and the Impact of

Indexing Initiatives". Economic Inquiry 22 (January): 1-17.

(1984b). "Valuing Pensions (Annuities) with Different Types of

Inflation Protection in Total Compensation Comparisons". Canadian

Journal of Economics 17 (August): 569-87.

(1985). "The Usefulness of the Wind-Up Measure of Pension

Liabilities: A Labor Market Perspective". Journal of Finance, 40: No.3 (July): $927-940$.

Salop, J. and S. Salop (1976). "Self-Selection and Turnover in the Labor

Market". Quarterly Journal of Economics (July), pp.619-27.

Sharpe, William (1976). "Corporate Pension Funding Policy". Journal of

Financial Economics 3 (June): 1983-93.

Statistics Canada (1979). Pension Plans in Canada 1978 (Ottawa: Government of Canada). 
Tepper, Irwin (1981). "Taxation and Corporate Pension Policy". Journal of Finance 36 (March 1981): 1-14.

Wise, David A. and Laurence Kotlikoff (1984). "Labor Compensation and the Structure of Private Pension Plans: Evidence for Contractual Versus Spot Labor Markets". National Bureau of Economic Research, Working Paper No. 1290, March. 
Table 1

Wage Paths Under the Spot Model of the Labour Market: "Generous" Plan with Typical Vesting and Early Retirement Provisions

\begin{tabular}{|c|c|c|c|c|}
\hline \multirow[b]{2}{*}{$\begin{array}{l}\text { Emp loyment } \\
\text { Year }\end{array}$} & \multicolumn{2}{|c|}{ Nominal Benefit } & \multicolumn{2}{|c|}{ Real Benefit } \\
\hline & $\begin{array}{l}\text { Level of } \\
\text { Real Wages } \\
\end{array}$ & $\begin{array}{l}\text { Growth Rate of } \\
\text { Real Wages }(\%)\end{array}$ & $\begin{array}{l}\text { Level of } \\
\text { Real Wages } \\
\end{array}$ & $\begin{array}{l}\text { Growth Ra } \\
\text { Real Wage }\end{array}$ \\
\hline $\begin{array}{l}1 \\
2 \\
3 \\
4 \\
5 \\
6 \\
7 \\
8 \\
9 \\
10 \\
11 \\
12 \\
13 \\
14 \\
15 \\
16 \\
17 \\
18 \\
19 \\
20 \\
21 \\
22 \\
23 \\
24 \\
25 \\
26 \\
27 \\
28 \\
29 \\
30 \\
31 \\
32 \\
33 \\
34 \\
35\end{array}$ & $\begin{array}{r}10,183 \\
10,370 \\
11,560 \\
10,754 \\
10,951 \\
11,152 \\
11,357 \\
11,565 \\
11,777 \\
11,339 \\
12,066 \\
12,262 \\
12,457 \\
12,651 \\
12,828 \\
13,026 \\
13,209 \\
13,386 \\
13,557 \\
13,719 \\
13,872 \\
14,013 \\
14,141 \\
14,254 \\
2,481 \\
14,363 \\
15,202 \\
16,125 \\
17,162 \\
15,420 \\
20,064 \\
21,905 \\
24,198 \\
26,582 \\
28,442\end{array}$ & $\begin{array}{r}1 . \\
1.83 \\
1.83 \\
1.83 \\
1.83 \\
1.83 \\
1.83 \\
1.83 \\
1.83 \\
-3.72 \\
6.41 \\
1.62 \\
1.59 \\
1.55 \\
1.40 \\
1.55 \\
1.40 \\
1.34 \\
1.27 \\
1.19 \\
1.12 \\
1.02 \\
0.91 \\
0.80 \\
-82.59 \\
478.86 \\
5.85 \\
6.07 \\
6.43 \\
-10.15 \\
30.12 \\
9.17 \\
10.47 \\
9.85 \\
7.00\end{array}$ & $\begin{array}{l}10,183 \\
10,370 \\
11,560 \\
10,754 \\
10,951 \\
11,152 \\
11,357 \\
11,565 \\
11,777 \\
10,614 \\
11,906 \\
12,073 \\
12,234 \\
12,390 \\
12,474 \\
12,657 \\
12,779 \\
12,889 \\
12,983 \\
13,054 \\
13,116 \\
13,152 \\
13,166 \\
13,156 \\
-8,149 \\
12,999 \\
14,125 \\
15,389 \\
16,843 \\
10,179 \\
21,549 \\
24,737 \\
28,486 \\
32,769 \\
34,795\end{array}$ & $\begin{array}{r}1.83 \\
1.83 \\
1.83 \\
1.83 \\
1.83 \\
1.83 \\
1.83 \\
1.83 \\
-9.88 \\
12.18 \\
1.40 \\
1.34 \\
1.27 \\
0.68 \\
1.46 \\
0.97 \\
0.85 \\
0.73 \\
0.55 \\
0.48 \\
0.28 \\
0.11 \\
-0.08 \\
-161.95 \\
-259.51 \\
8.66 \\
8.95 \\
9.45 \\
-39.56 \\
111.70 \\
14.79 \\
15.16 \\
15.04 \\
6.18\end{array}$ \\
\hline
\end{tabular}

Notes: The pension benefit is $2 \%$ of the worker's average earnings during the past 5 years for each year of service. Benefits vest after 10 years of service and the worker is eligible for an early retirement benefit at age 55 . If he elects to retire at age 55, he receives immediately a life annuity equal to 70 percent of the benefit due him at age 65; at age 56, 73 percent; and so forth.

The worker is presumed to enter the plan at age 30 . The interest rate is $12 \%$, the inflation rate is $9 \%$, and the nominal value of the worker's marginal product grows at $11 \%$ per year. The initial value of the worker's marginal product is $\$ 10,000$ and it grows in real terms at an implied annual rate of 1.83\%. The risk free real interest rate used to value the indexed annuities is one percent. If the worker terminates prior to qualifying for an early retirement pension, his benefit remains fixed in nominal terms until he reaches normal retirement at age 65 , and is then indexed to the inflation rate. 
Table $1 A$

Wage Paths Under the Spot Model of the Labour Market: "Less Generous" Plan with Typical Vesting and Early Retirement Provisions

\begin{tabular}{|c|c|c|c|c|}
\hline \multirow[b]{2}{*}{$\begin{array}{l}\text { Emp loyment } \\
\text { Year }\end{array}$} & \multicolumn{2}{|c|}{ Nominal Benefit } & \multicolumn{2}{|c|}{ Real Benefit } \\
\hline & $\begin{array}{l}\text { Level of } \\
\text { Real Wages } \\
\end{array}$ & $\begin{array}{l}\text { Growth Rate of } \\
\text { Real Wages }(\%)\end{array}$ & $\begin{array}{l}\text { Level of } \\
\text { Real Wages } \\
\end{array}$ & $\begin{array}{l}\text { Growth Rate of } \\
\text { Real Wages }(\%)\end{array}$ \\
\hline 1 & 10,183 & - & 10,183 & - \\
\hline 2 & 10,370 & 1.83 & 10,370 & 1.83 \\
\hline 3 & 11,560 & 1.83 & 11.560 & 1.83 \\
\hline 4 & 10,754 & 1.83 & 10,754 & 1.83 \\
\hline 5 & 10,951 & 1.83 & 10,951 & 1.83 \\
\hline 6 & 11,152 & 1.83 & 11,152 & 1.83 \\
\hline 7 & 11,357 & 1.83 & 11,357 & 1.83 \\
\hline 8 & 11,565 & 1.83 & 11,565 & 1.83 \\
\hline 9 & 11,777 & 1.83 & 11,777 & 1.83 \\
\hline 10 & 11,664 & -0.96 & 11,294 & -4.11 \\
\hline 11 & 12,139 & 4.07 & 12,056 & 6.75 \\
\hline 12 & 12,349 & 1.73 & 12,250 & 1.61 \\
\hline 13 & 12,560 & 1.71 & 12,443 & 1.57 \\
\hline 14 & 12,772 & 1.69 & 12,634 & 1.54 \\
\hline 15 & 12,982 & 1.64 & 12,806 & 1.36 \\
\hline 16 & 13,198 & 1.66 & 13,003 & 1.53 \\
\hline 17 & 13,411 & 1.61 & 13,182 & 1.38 \\
\hline 18 & 13,623 & 1.58 & 13,354 & 1.31 \\
\hline 19 & 13,833 & 1.54 & 13,520 & 1.24 \\
\hline 20 & 14,041 & 1.50 & 13,676 & 1.15 \\
\hline 21 & 14,245 & 1.46 & 13,822 & 1.07 \\
\hline 22 & 14,445 & 1.40 & 13,956 & 0.97 \\
\hline 23 & 14,639 & 1.34 & 14,075 & 0.86 \\
\hline 24 & 14,826 & 1.28 & 14,179 & 0.74 \\
\hline 25 & 7,669 & -48.28 & $-1,521$ & -110.73 \\
\hline 26 & 15,140 & 97.42 & 14,334 & $-1,042.26$ \\
\hline 27 & 15,836 & 4.60 & 15,478 & 7.98 \\
\hline 28 & 16,598 & 4.81 & 16,746 & 8.19 \\
\hline 29 & 17,441 & 5.08 & 18,169 & 8.50 \\
\hline 30 & 17,291 & -0.86 & 15,334 & -15.61 \\
\hline 31 & 19,618 & 13.46 & 22,259 & 45.16 \\
\hline 32 & 20,916 & 6.67 & 24,917 & 11.94 \\
\hline 33 & 22,492 & 7.54 & 27,937 & 12.12 \\
\hline 34 & 24,088 & 7.10 & 31,252 & 11.86 \\
\hline 35 & 25,643 & 6.45 & 33,999 & 8.79 \\
\hline
\end{tabular}

Notes: Same as in Table 1, except that pension benefit is now $1 \%$ of the worker's average earnings for each year of service. 
$\underline{\text { Table } 2}$

The Impact of Different Economic Environments on Wage Paths Under the Spot Model: "Generous" Plan with Nominal Benefit

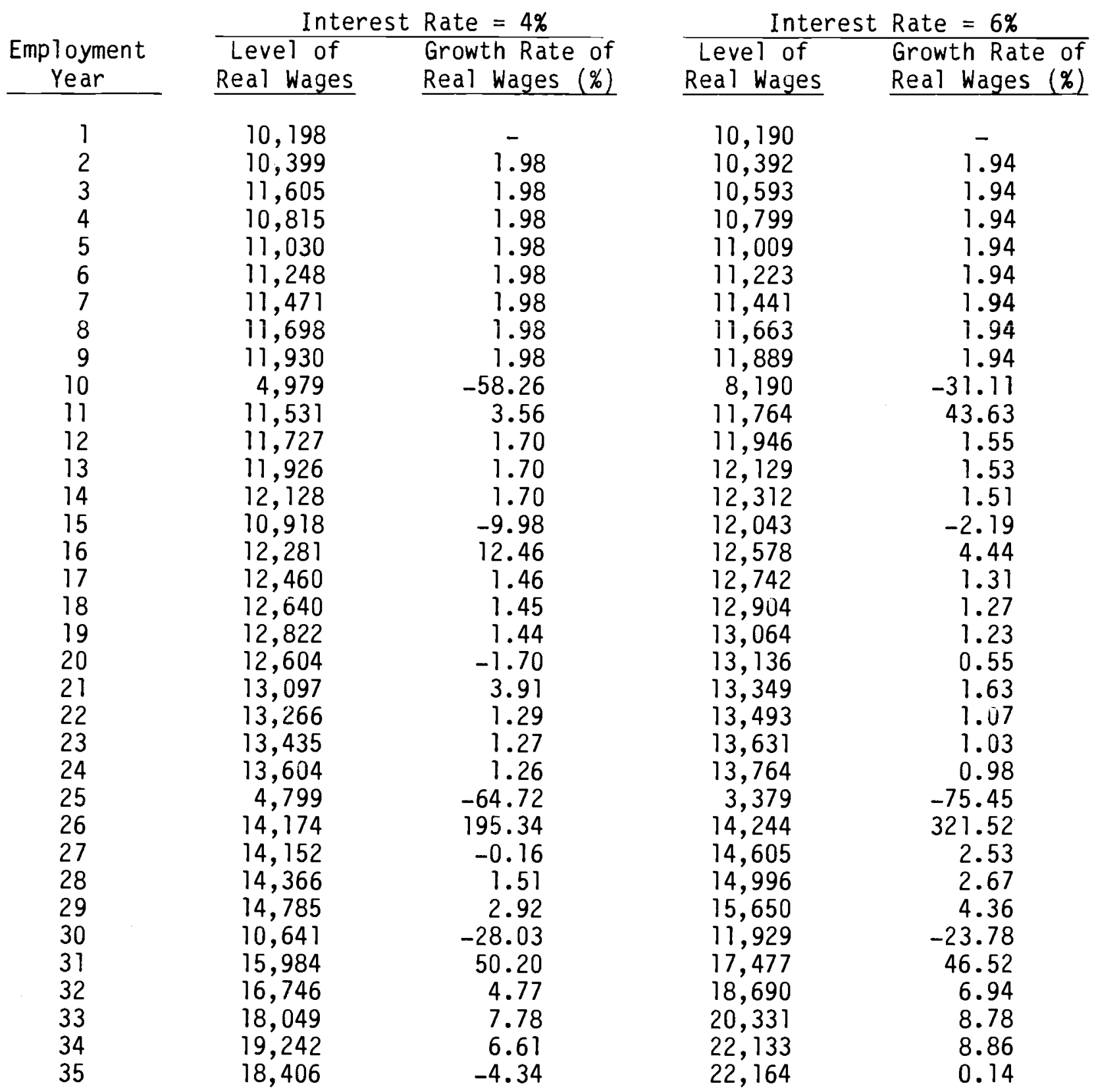

Notes: Same as in Table 1, except for different economic assumptions. When the interest rate is $4 \%$, the inflation rate is $1 \%$ and the nominal value of the worker's marginal product grows at $3 \%$ per year. When the interest rate is $6 \%$, the inflation rate is $3 \%$ and the nominal value of the worker's marginal product grows at $5 \%$ per year. 


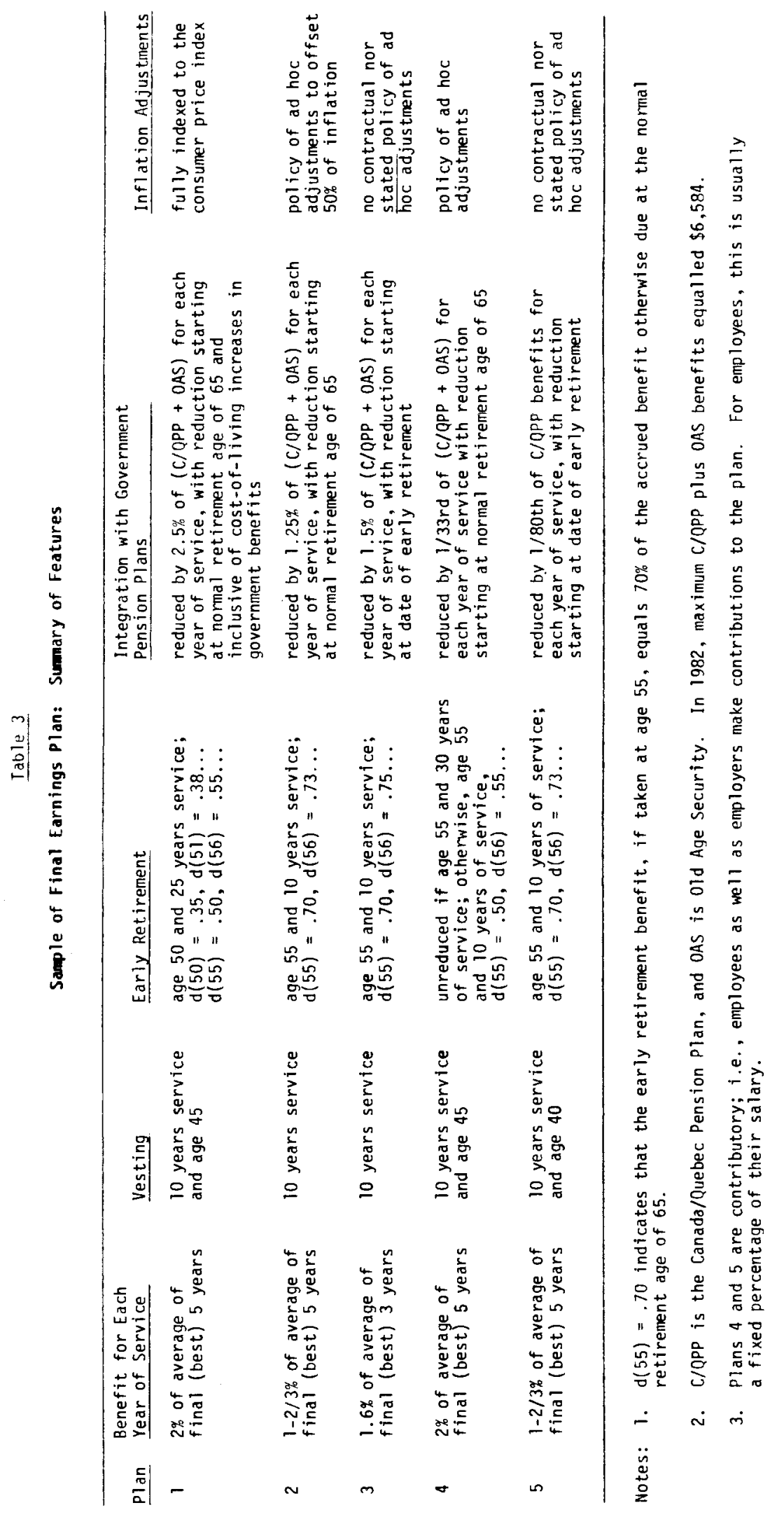


$\underline{\text { Table } 4}$

Benefit Accruals in 1982: Plan with Early Retirement

at Age 50 and 25 Years of Service

\begin{tabular}{lrr}
$\begin{array}{l}\text { Service } \\
\text { Cohort }\end{array}$ & $\begin{array}{c}\text { Benefit } \\
\text { Accrual }\end{array}$ & $\begin{array}{c}\text { Accrual/ } \\
\text { Wage }\end{array}$ \\
\cline { 2 - 3 } & & \\
21 & 2,826 & 0.07 \\
22 & 3,174 & 0.08 \\
23 & 4,318 & 0.09 \\
24 & 4,066 & 0.10 \\
25 & 65,149 & 1.40 \\
26 & 16,356 & 0.35 \\
27 & 16,305 & 0.36 \\
28 & 17,196 & 0.36 \\
29 & 16,231 & 0.33 \\
30 & 13,348 & 0.31 \\
31 & 20,678 & 0.47 \\
32 & 18,839 & 0.42 \\
33 & 23,172 & 0.53 \\
34 & 21,748 & 0.49 \\
35 & 13,058 & 0.28
\end{tabular}

Notes:

1. This is Plan No. 1 in Table 3.

2. A cross-tabulation of male workers by age and years of service indicates that the majority of workers with 25 years of service have attained age 50. The calculations presume that a worker who completes his 25 th year of service also attains age 50 and thus qualifies for an early retirement benefit.

3. The pension benefit is an indexed life annuity which is valued at a real interest rate of $1 \%$. 


\section{Benefit Accruals in 1982: Plansa with Early Retirement} at Age 55 and 10 Years of Service

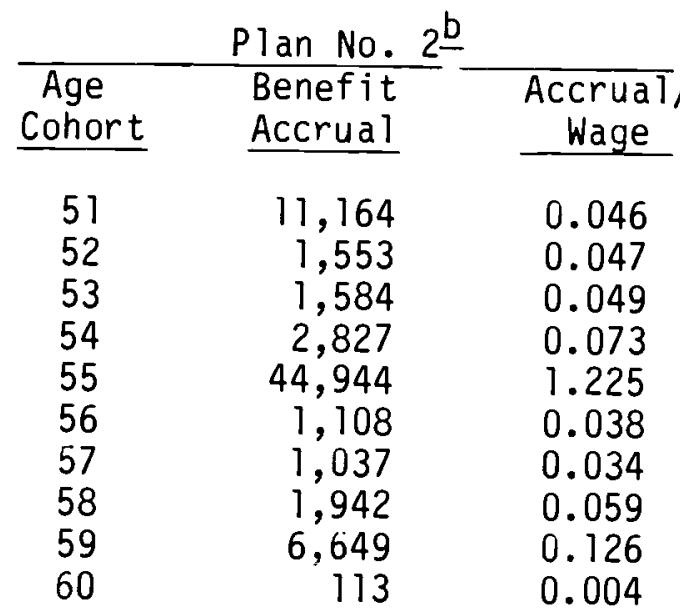

\begin{tabular}{|c|c|c|}
\hline $\begin{array}{c}\text { Age } \\
\text { Cohort }\end{array}$ & $\begin{array}{l}\text { Plan No. } \\
\text { Benefit } \\
\text { Accrual }\end{array}$ & $\begin{array}{c}\text { Accruat/ } \\
\text { Wage }\end{array}$ \\
\hline $\begin{array}{l}51 \\
52 \\
53 \\
54 \\
55 \\
56 \\
57 \\
58 \\
59 \\
60\end{array}$ & $\begin{array}{r}1,714 \\
2,170 \\
2,351 \\
2,718 \\
37,236 \\
5,853 \\
6,278 \\
6,475 \\
7,179 \\
6,380\end{array}$ & $\begin{array}{l}0.046 \\
0.055 \\
0.063 \\
0.072 \\
0.959 \\
0.155 \\
0.144 \\
0.160 \\
0.169 \\
0.169\end{array}$ \\
\hline
\end{tabular}

\begin{tabular}{|c|c|c|}
\hline $\begin{array}{c}\text { Age } \\
\text { Cohort }\end{array}$ & $\begin{array}{l}\text { Plan No. } \\
\text { Benefit } \\
\text { Accrual }\end{array}$ & $\begin{array}{c}\text { Accrual } \\
\text { Wage }\end{array}$ \\
\hline $\begin{array}{l}51 \\
52 \\
53 \\
54 \\
55 \\
56 \\
57 \\
58 \\
59 \\
60\end{array}$ & $\begin{array}{r}1,488 \\
1,435 \\
1,780 \\
2,261 \\
29,079 \\
8,636 \\
4,465 \\
5,211 \\
1,194 \\
20,324\end{array}$ & $\begin{array}{l}0.049 \\
0.053 \\
0.064 \\
0.075 \\
0.853 \\
0.192 \\
0.123 \\
0.150 \\
0.058 \\
0.739\end{array}$ \\
\hline
\end{tabular}

\begin{tabular}{|c|c|c|}
\hline \multicolumn{3}{|c|}{ Plan No. 5} \\
\hline $\begin{array}{c}\text { Age } \\
\text { Cohort }\end{array}$ & $\begin{array}{l}\text { Benefit } \\
\text { Accrual }\end{array}$ & $\begin{array}{c}\text { Accrual } \\
\text { Wage } \\
\end{array}$ \\
\hline $\begin{array}{l}51 \\
52 \\
53 \\
54 \\
55 \\
56 \\
57 \\
58 \\
59 \\
60\end{array}$ & $\begin{array}{r}1,280 \\
1,081 \\
1,680 \\
2,034 \\
32,850 \\
2,824 \\
2,837 \\
5,096 \\
539 \\
1,066\end{array}$ & $\begin{array}{l}0.042 \\
0.036 \\
0.052 \\
0.059 \\
1.001 \\
0.084 \\
0.095 \\
0.114 \\
0.014 \\
0.027\end{array}$ \\
\hline
\end{tabular}

\section{Notes:}

a. See Table 3 for plan details. Calculations assume that workers who are age 55 have completed 25 years of service.

b. The sponsor of Plan No. 2 provides, as a matter of policy, cost-of-living adjustments designed to offset the impact on pensions in pay of $50 \%$ of the increase in inflation as measured by the consumer price index. Terminated workers entitled to deferred annuities receive such adjustments only after they attain normal retirement age of 65. Discounting at an interest rate of $6 \%$ is a crude attempt to allow for such adjustments. At this interest rate, the benefit accrued at age 55 rises to $\$ 72,932$ or to 1.989 times the average cash wage paid to this age cohort.

c. If the plan member has completed 30 years of service at age 55 , as more than $50 \%$ have, he qualifies for an unreduced early retirement benefit. For such members, the benefit accrued at age 55 is actually $\$ 84,923$ or 2.492 times the average cash wage paid to this age cohort. At age 60 , a member is assumed to have completed 30 years of service and thus qualifies for an unreduced benefit. This explains the discontinuity at age 60 . 
Table 6

Benefit Accruals for Service/Age Cohorts at Time of Vesting

Plan No. $1^{\text {a }}$

$\left(10\right.$ Years Service and age 45) Plan No.2 (10 Years Service) ${ }^{\mathrm{b}}$ Plan No.3 (10 Years Service) ${ }^{\mathrm{b}}$

\begin{tabular}{|c|c|c|c|c|c|c|c|c|}
\hline $\begin{array}{c}\text { Age } \\
\text { Cohort }\end{array}$ & $\begin{array}{l}\text { Benefit } \\
\text { Accrual } \\
\end{array}$ & $\begin{array}{c}\text { Accrual/ } \\
\text { Wage }\end{array}$ & $\begin{array}{l}\text { Service } \\
\text { Cohort }\end{array}$ & $\begin{array}{l}\text { Benefit } \\
\text { Accrual }\end{array}$ & $\begin{array}{c}\text { Accrual/ } \\
\text { Wage }\end{array}$ & $\begin{array}{l}\text { Service } \\
\text { Cohort }\end{array}$ & $\begin{array}{l}\text { Benef it } \\
\text { Accrual } \\
\end{array}$ & $\begin{array}{c}\text { Accrual/ } \\
\text { Wage }\end{array}$ \\
\hline $\begin{array}{l}44 \\
45 \\
46 \\
47\end{array}$ & $\begin{array}{r}0 \\
12,229 \\
2,793 \\
3,439\end{array}$ & $\begin{array}{c}0 \\
0.299 \\
0.066 \\
0.077\end{array}$ & $\begin{array}{r}9 \\
10 \\
11 \\
12\end{array}$ & $\begin{array}{c}0 \\
1,171 \\
639 \\
781\end{array}$ & $\begin{array}{c}0 \\
0.035 \\
0.012 \\
0.013\end{array}$ & $\begin{array}{r}9 \\
10 \\
11 \\
12\end{array}$ & $\begin{array}{c}0 \\
1,256 \\
371 \\
898\end{array}$ & $\begin{array}{c}0 \\
0.038 \\
0.010 \\
0.026\end{array}$ \\
\hline
\end{tabular}

Plan No. $4^{\mathrm{C}}$

(10 Years Service and Age 45)

Plan No. $5^{d}$

$(10$ Years Service and Age 40$)$

\begin{tabular}{|c|c|c|}
\hline $\begin{array}{c}\text { Age } \\
\text { Cohort }\end{array}$ & $\begin{array}{l}\text { Benefit } \\
\text { Accrual }\end{array}$ & $\begin{array}{c}\text { Accrual } \\
\text { Wage }\end{array}$ \\
\hline $\begin{array}{l}44 \\
45 \\
46 \\
47\end{array}$ & $\begin{array}{c}0 \\
3,018 \\
648 \\
678\end{array}$ & $\begin{array}{c}0 \\
0.086 \\
0.022 \\
0.025\end{array}$ \\
\hline
\end{tabular}

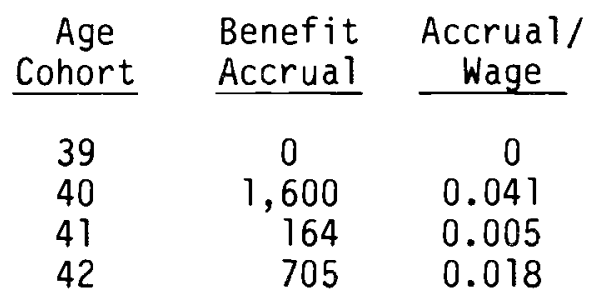

Notes:

a. If a plan member terminates before qualifying for an early retirement benefit, his deferred pension is fixed in nominal terms until he reaches normal retirement age of 65 , and then rises at the inflation rate. A terminated worker entitled to a deferred pension is presumed to receive a death benefit equal to the present value of the deferred pension at the date of his death.

b. Assumes that those completing 10 years of service have attained age 40 . For Plan 2, benefit accrued by 10 -year service cohort rises to $\$ 1,793$ if the deferred annuity is valued at an interest rate of $6 \%$, to reflect the sponsor's policy of providing ad hoc cost-of-living adjustments for pensions in pay equal to $50 \%$ of the inflation rate.

c. Assumes that those attaining age 45 have 15 years of service. If they have 20 years of service, the benefit accrued by this age cohort rises to $\$ 4,024$.

d. Assumes that those attaining age 40 have completed 10 years of service. If they have completed 15 years of service, the benefit accrued by this age cohort rises to $\$ 2,400$.

Plans 4 and 5 are contributory, and terminated workers whose benefits have not vested receive the accumulated value of their own contributions. This fact is not reflected in the calculations reported above, and the calculations significantly overstate the benefit accrual associated with vesting in these two plans on this account. 